DOI https://doi.org/10.18551/rjoas.2017-11.37

\title{
ANALYSIS OF ABNORMAL RETURN, STOCK RETURN AND STOCK LIQUIDITY BEFORE AND AFTER BUYBACK SHARE: CASE STUDY OF COMPANIES LISTED IN INDONESIA STOCK EXCHANGE IN PERIOD OF 2011-2015
}

\author{
Amin Mohammad Arridho Nur*, Ramdhani Dadan \\ University of Esa Unggul, Tanggerang, Indonesia \\ *E-mail: mohammad.arridho@gmail.com
}

\begin{abstract}
This study aims to know the impact of buyback share conducted by companies listed on the Indonesia Stock Exchange (IDX) Period of 2011-2015. The analytical method used to perform the test of this research's hypothesis is parametric t statistic which is by using two different mean tests with paired samples. The population in this study is all listed companies in Indonesia Stock Exchange (IDX) which conduct buyback share from the period of 2011 to the period of 2015. The results of this study include 1) the first hypothesis shows that on average, abnormal share return prior to the implementation of buyback share is greater than after the implementation of buyback share, 2) the second hypothesis, on average, stock return prior to the execution of buyback share is larger compared to after the implementation of buyback share, stock return of the company after the implementation of share buyback, 3 ) the third hypothesis shows, on average, trading volume activity after implementation buyback share is greater than before implementation, 4) The fourth hypothesis after testing the result shows the bid-ask spread after the implementation of buyback share which is greater than before buyback share.
\end{abstract}

\section{KEY WORDS}

Abnormal return, buyback share, stock liquidity, stock return.

Company listed on the Indonesia Stock Exchange (BEI) obtains source of funding through the transaction of financial instruments in the capital market; when the company has entered the capital market, and then the information of the company will be widely disseminated so that investors can assess the condition of the company. An announcement made by company in the capital market that have information content will get reactions from investors, if the information brings reliable and high-quality signals, (Chemmanur and Li, 2014). The quality of the information can be reflected through the conditions of company fundamentals, (Kollmann, 2006). The company that has condition which is fundamentally good and trusted by investors, it will be indistinguishable from companies that have fundamentally less reliable condition, because the signal given by the company can be positive or negative for such investors, resulting in a reaction from investors to the information reveals that investors believe in the condition of the company in the future, (Feeney et al.,1999).

The capital market will react to any information from the company to achieve a new balance price is a very important thing, (Brown, 2007). Because of information, it will result in changes in the company's stock price at company, so the returns will also change as well as the perception of investors are changing and investment decision-making is also changing. While, the reaction to information is usually investigated by using event study. Event study is a study that learns about the market reaction toward an event which its information is published as an announcement in the capital market, so this event study can be used to test the information content of an announcement and it may also be used to test the market efficiency of the half-strong form, especially formal audit information, (Jegadeesh and Titman, 1993; Fama, 1998)

Go-public company that has been registered or listed in Stock Exchange Indonesia (IDX requires the management of the company to work professionally. In this way, the company will provide information both to the public and to investors, information in the 
market capital can be a signal that one of them affects stock prices either positively or negatively in the capital market. If it gives positive impact, then the investors will compete to enter into the capital market and fight over those shares, so that the price of the stock is boosted up, then another company's goal that is improving the welfare for its share-holder will be achieved, Veronica Siregar and Bachtiar, 2010). If the impact is negative, then it is made sure that investors will be doubtful and unwilling to invest more money in the company, as well as investors will sell the shares that they have. Information plays a role important in projecting stock prices in the secondary market; the secondary market in this case is the Indonesia Stock Exchange (IDX). The fast reaction to the information provided by the company to the market can be interpreted that the market has been efficient in receiving such information. The market will react to any information to reach the price of the new balance (Jogiyanto, 2013).

Information regarding to shareholders (stockholders are much utilized by the management in maintaining stock prices to avoid undervalued (stock prices that occur in the market is lower than the fair price or the so-called value fundamental stocks). The increasing stock price is one of the factors supporting the company is considered having good performance. Therefore, the relationship between the rise and the fall of stock prices, one of them, can be influenced by the performance of the company. The role of the influential information in presenting the stock price at market exchange is encouraging the Indonesian government through the Supervisory Board of Capital Market and Financial Institution (BAPEPAM-LK) to issue a regulation related to information openness that must be announced to public.

\section{METHODS OF RESEARCH}

The analytical method used to perform the test of this research hypothesis is parametric $t$ statistic that is by using two different mean tests with paired samples (sample ttest paired Ghozali (2012). Statistical analysis used in this research is difference test of paired sample t-test using statistical software. This research is descriptive comparative meaning that looking for differences before and after the company conducts buyback share. According to Nazir (2005), comparative research is a kind of descriptive research that is willing to find answers fundamentally about cause and effect which is by analyzing the factors of the cause or occurrence of a particular phenomenon.

The population in this study is all companies which are listed in the Indonesia Stock Exchange (IDX) conducting buyback share in the period of 2011 to 2015 . Determination of sample in this research is done by using method of purposive sampling. By purposive sampling method, it is selected based on predetermined criteria. The criterion used by researchers in this research is a company that is a go-public company which is listed in the Indonesia Stock Exchange (IDX) in the period of 2011 to 2015. The company conducts buyback share based on Bapepam-LK regulation number XI.B.2 and the regulation number XI.B.3 (appendix B and C), and available data on the date of the buyback share announcement. Shares of companies conducting active buybacks traded over the estimated period and window period. Availability of data regarding to the date of buyback share announcement is available on the annual report or www.idx.co.id in the section of corporate action.

\section{RESULTS AND DISCUSSION}

Abnormal Testing of Return on Buyback Share. It is the test result of paired sample $t$ test of abnormal return on average for three days before and after the implementation of buyback share. The result calculation using computer SPSS program obtained significance abnormal returns before and abnormal return after implementation of 0,744 which is greater than the 0.05 significance level. Testing on average (mean abnormal return before the implementation of buyback share that is equal to 0,00145 and abnormal return after the implementation stock buyback of $-0,00184$. It is decided that abnormal average return before 
the implementation of buyback share is greater than average abnormal returns after the implementation of buyback share, therefore $\mathrm{H} 1$ is rejected and $\mathrm{H} 0$ is accepted. The decrease of abnormal share returns is caused by falling stock prices of companies in the post exchange of the implementation of buyback share. It is caused by investors who do not respond maximally to the implementation of buyback share.

Table 1 - Test Result of Paired Samples $t$ test of Abnormal Return in Date around Buyback Share Announcement (On Average)

\begin{tabular}{ccc}
\hline Period & Significance & Mean \\
\hline AAR Before & 0,744 & 0,001454 \\
AAR After & & $-0,001845$ \\
\hline
\end{tabular}

Testing Share Return on Buyback Share. The test results show the results of paired sample $t$ test for share return on average during the observation period is three days before and after the implementation of buyback share published. The calculation results using computer program SPSS obtained the significance of share return before and share return after the implementation of 0,698 which is greater than the level significance of 0.05 . On the test results of average share return using paired sample $t$ test mean share return obtained in the period before the buyback share is equal to 0,003213 and after the buyback share is 0,000261 . Hence, based on test result of paired sample t-test mean value of share return before and after indicates that the mean prior to the implementation of the buyback share is greater than the mean after the implementation of the buyback share. Thus, the conclusion is that $\mathrm{H} 2$ is rejected and $\mathrm{H} 0$ is accepted or average return shares before the implementation of buyback share is greater than after the implementation of buyback share. The negative value of stock return is caused by the decrease in stock prices of companies in the share market; it causes continued decrease in the rate of return (return on the company. So the stock returns in the period after the implementation of buyback share is negative.

Table 2 - Test Result of Paired Samples $t$ test of Abnormal Return in Date around Buyback Share Announcement (On Average)

\begin{tabular}{ccc}
\hline Period & Significance & Mean \\
\hline ARS Before & 0,698 & 0,003213 \\
ARS After & & $-0,000261$ \\
\hline
\end{tabular}

Testing of Trading Volume Activity on Buyback Share. Variable testing of trading volume activity shows the test result using paired sample $t$ tests on average during three days before and after the implementation of buyback share published. The calculation results using computer SPSS program obtained value trading volume activity significance before trading volume activity after announcement of 0,397 is greater than the level significance of 0.05 . The average test result of trading volume activity using paired test sample test mean trading volume activity obtained in the period before the buyback share is equal to 0,00153 and after the buyback share is of 0.00200 . From the comparison results of the significance value of trading activity volume before and after the implementation of buyback share and according to previous research, it is found that if the value of the paired different test results is significantly greater than 0.05 , then it is stated that there is no difference, but from the comparison of mean or average trading volume activity before implementation is 0,001537 and after the implementation is 0,00200. Thus, the mean after the implementation of the buyback share is greater than before the implementation of buyback share, then it is concluded that $\mathrm{H}_{3}$ is accepted and $\mathrm{H}_{0}$ is rejected. The increase of share trading volume is caused by the majority of investors buy stocks at the limit price of certain stocks, so that the increase in sales volume increases, but on the abnormal return and share return do not have positive value as well as it cannot provide maximum return post implementation buyback share. 
Table 3 - Test Results of Paired TVA Sample Test in Date of Buyback Share Announcement (On Average)

\begin{tabular}{ccc}
\hline Period & Significance & Mean \\
\hline ATVA Before & 0,397 & 0,001537 \\
ATVA After & & 0,002003 \\
\hline
\end{tabular}

Testing of Bid Ask Spread on Buyback Share. The data above shows the results of paired sample $t$ of test bid-ask spread on average for three days before and after the implementation of buyback share is published. The calculation results using computer program SPSS obtained significant value of bid-ask spread before and bid ask-spread after the announcement of 0,115 which is greater than the 0,05 significance level. In the calculation of the average value (mean before the implementation of buyback share amounted to 0,021041 and in the period after the implementation of buyback share amounts to 0,028022 ). When viewed from the mean value after implementation of buyback share is larger than before implementation, it is decided that the average bid ask spread after implementation of buyback share is greater than before buyback share, so $\mathrm{H}_{4}$ is accepted and $\mathrm{H}_{0}$ is rejected.

Table 4 - Test Result of Paired Sample t test of Bid Ask-Spread in Date of Buyback Share Announcements (On Average)

\begin{tabular}{ccc}
\hline Period & Significance & Mean \\
\hline ABAS Before & 0,115 & 0,021041 \\
ABAS After & & 0,028022 \\
\hline
\end{tabular}

The value of average positive spread is caused by the increase of company's share trading volume after the implementation of buyback share. It occurs because the investor buy more company' share after the implementation of buyback share, but purchases made by investors still has not improved as expected by the company which is proven by an increase in the spread that occurs only by 0,0069 after the implementation of buyback share.

\section{DISCUSSION OF RESULTS}

This study is conducted to test whether there is a market reaction around the date of publication of corporate action that is buyback share policy, and to see if there are differences in market reaction before and after the publication of the policy. The market reaction intended in this study is the reaction of the abnormal return of stock, trading volume activity and bid ask spread that happened for three days before and after publication of the announcement of buybacks done.

Table 5 - Hypothesis Statement

\begin{tabular}{|c|c|c|c|}
\hline Hypothesis & Statement & $\begin{array}{l}\text { Mean } \\
\text { Before and } \\
\text { After }\end{array}$ & Information \\
\hline H 1 & $\begin{array}{c}\text { Average Abnormal Share Return } \\
\text { Cumulative is bigger than after buyback share than } \\
\text { before buyback share. }\end{array}$ & $\begin{array}{c}0,0014>- \\
0,0018\end{array}$ & $\begin{array}{c}\text { Data is not supporting } \\
\text { Hypothesis }\end{array}$ \\
\hline $\mathrm{H} 2$ & $\begin{array}{c}\text { Average Cumulative Share Return } \\
\text { Is bigger than after buyback share than before } \\
\text { buyback share. }\end{array}$ & $\begin{array}{c}0,0032>- \\
0,0002\end{array}$ & $\begin{array}{l}\text { Data Is not Supporting } \\
\text { hypothesis }\end{array}$ \\
\hline $\mathrm{H} 3$ & $\begin{array}{c}\text { Average trading volume activity } \\
\text { Cumulatively after buyback share is bigger than } \\
\text { before buyback share. }\end{array}$ & $\begin{array}{c}0,0015< \\
0,0020\end{array}$ & $\begin{array}{c}\text { Data is supporting } \\
\text { hypothesis }\end{array}$ \\
\hline $\mathrm{H} 4$ & $\begin{array}{c}\text { Average of bid ask spread } \\
\text { Cumulatively after buyback share is bigger than } \\
\text { before buyback share }\end{array}$ & $\begin{array}{c}0,0210< \\
0,0280\end{array}$ & $\begin{array}{l}\text { Data is supporting } \\
\text { hypothesis }\end{array}$ \\
\hline
\end{tabular}


Abnormal reaction of return share, trading volume activity, and bid ask spread on buyback share in this research is explained as follows:

Abnormal Reaction of Return on Buyback Share. From the test, it is found that there is a significant difference tendency in some periods of events that is on period $t-3, t-2, t+2$, and $t+3$. It reinforces the finding that buyback shares have certain information or signal that can be influencing investor's decision in doing transaction over normal decisions. The existence of significant differences statistically between the average daily abnormal return before and after buyback share announcements on a given day reflects that the capital market in Indonesia as a whole has not anticipated the existence of buyback share information.

Table 5 - Table of Average Abnormal Company's Share Return

\begin{tabular}{|c|c|}
\hline Period & Average \\
\hline$t-3$ & $-0,012521$ \\
\hline$t-2$ & 0,012050 \\
\hline$t-1$ & 0,004831 \\
\hline$t 0$ & $-0,013092$ \\
\hline$t+1$ & 0,001757 \\
\hline$t+2$ & $-0,000500$ \\
\hline$t+3$ & $-0,006792$ \\
\hline
\end{tabular}

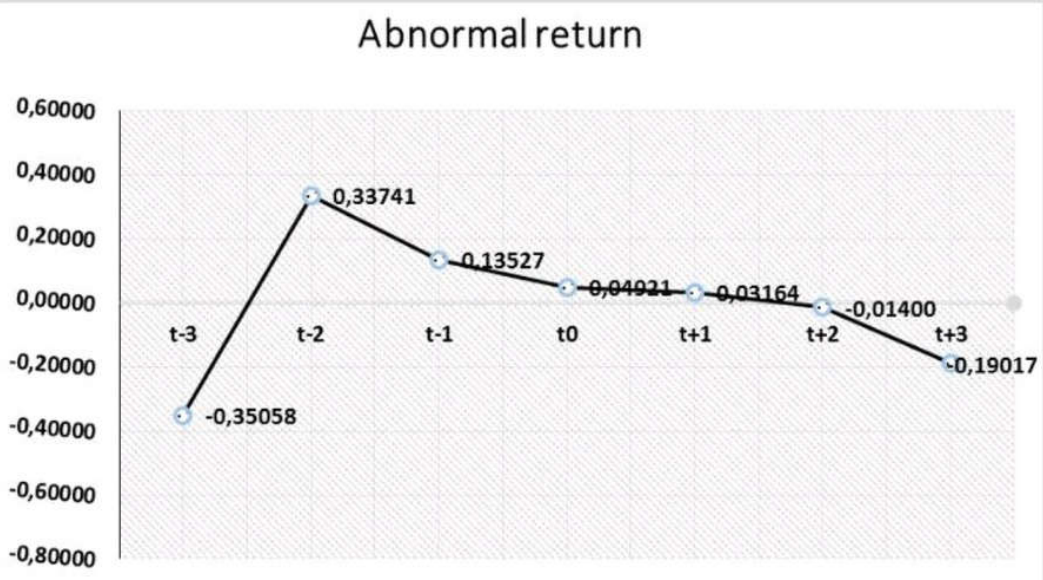

Figure 1 - Average Movement of Abnormal Sample Return during Windows Period of Buyback Share Announcement Year of 2011-2015 (Source: BAPEPAM-LK and BEl that have been reprocessed for this study, 2017)

The movement of the abnormal return in the period figure before and after in the windows period that the reaction of average abnormal returns is larger than before the implementation of significant buyback share in the event period. It happens because of the tendency of the average abnormal return reacts over a period of time not evenly distributed in the observed windows period. The highest abnormal return occurs at $\mathrm{t}-2$ in the observation period, which is up to 0,33741 . However, it decreases on $\mathrm{t}-1$ to $\mathrm{h}+1$ and decreases to abnormal returns which has negative value at $t+2$ and $t+3$ during the observation period. Positive abnormal return indicates that the level of profit that occurs in the company who do buyback shares are greater than with the profit expected by investors, so investors obtain a share return due to shares bought back by the company experience a price increase due to the event. However, the condition is only on $\mathrm{t}-2$ before the buyback share of corporate action, after $\mathrm{t}-2$ is on $\mathrm{t}+2$ abnormal return showing negative. It indicates that the level of profit incurred by the event of buyback share is smaller than the profit expected. The decrease in abnormal return is due to negative sentiment with the market caused by the current market conditions, where overall market share prices decreased or in the condition of down trend.

The value of the abnormal return on average showing that before the implementation of buyback share is greater than after the implementation of buyback share explain that the 
information brought regarding to the existence of buyback share announcement has not been able to provide a reasonable profit and not yet able to have a good impact to the company's stock price. However, investors still can obtain abnormal return on certain days before and after buyback share announcements made by company.

Abnormal return is a motive of the investor to buy shares when the company will conduct corporate action, (Hackethal and Zdantchouk, 2006). A positive abnormal return will benefit which is great towards investors, because of with the positive abnormal return, then investors who buy shares before the implementation of corporate action, the price of shares purchased after the company took a corporate action will tend to increase. It is very profitable for short-term investors due to rising stock prices companies that have been bought, when stock prices increase and directly on sale, then it will get a big capital gain.

The magnitude of the company's stock price increase after the implementation of corporate action depends on how much information which is absorbed in the market, (Huang and Zhou, 2007). More information obtained by investors and positively charged about the condition of the company, then the increase of the company's stock price will be increasing in accordance with the desired management company.

The graph on the picture also shows a downward trend on $t-1$ up to $t+0$, the decrease in the graph occurs to a negative value. It is due to the fact that stock prices decrease before and after the implementation of share buyback. Because of the fall in prices of the stock, it resulted in a negative abnormal return. However, although the abnormal return is negative in some days before and after buyback share, on a few days ahead of the implementation of buyback share and one day after the implementation of buyback share, abnormal return is positive so that investors keep enjoying an abnormal profit resulting from buyback share action.

The negative value shown is abnormal return due to the majority of investors who buy shares in the period before the implementation of buyback share, so the stock price boosted up leads to abnormal stock returns. However, after the implementation of buyback share, the interest of investors to buy shares of company that does buyback shares decreases, so the price of the company's stock also decreases to cause abnormal return decline and reach negative value.

The issuer expects the impact of the implementation of buyback share, which is the investor believes in the performance of the company resulting in rising stock prices. But, on condition of Indonesia's economy and viewed from the form of market efficiency, Indonesia is still included into strong-half form, then any investor still cannot get a balanced abnormal share return. If investors are long-term investors, then the implementation of buyback share becomes the consideration in buying the company's stock in the middle of fluctuating economy condition. It is viewed from the comparison of companies that conduct buyback share and publish bonds (obligation), then companies that do buyback share become the right choice. Because of the economic conditions that are getting worse, the company will seek funding sources to keep it operating in the midst of a crisis experienced by the company. But if it is for short-term investors, the decrease of abnormal returns becomes a signal to delay to invest in the company.

Reaction of Share Returns on Buyback Share. The value of the average daily share returns previously with the average of abnormal daily return after buyback share during the event period, on a company that has made buyback share in the observation period, i.e. three days before and three days after implementation of buyback share.

Table 6 - Table of Company's Average Share Return

\begin{tabular}{|c|c|}
\hline Period & Average \\
\hline $\mathrm{t}-3$ & $-0,00943$ \\
\hline $\mathrm{t}-2$ & 0,01124 \\
\hline $\mathrm{t}-1$ & 0,00783 \\
\hline $\mathrm{t} 0$ & 0,00737 \\
\hline $\mathrm{t}+1$ & 0,00228 \\
\hline $\mathrm{t}+2$ & 0,00297 \\
\hline $\mathrm{t}+3$ & $-0,00603$ \\
\hline
\end{tabular}


The table above is the value of the average daily stock return before the buyback share by being calculated from the average stock return as well as after buyback share during the period of events. From testing, it is found that there is a significant trend of differences in some period of events that is in period $t-3, t-2$, and $t+3$. This research reinforces the findings that buyback share contain information or specific signals that may influence the decision of investors in making transactions over normal decisions. There is a statistically significant difference between the mean of share return previously, i.e. on t-3 which has negative value of $-0,2639$. It indicates that there is no benefit to be gained by companies in the period of buyback share in the period before the implementation of buyback share, but when t-2 stock returns increases to form a number of 0,3147008 . It shows the existence of a good signal from investors, thereby raising stock prices so the stock return on $\mathrm{t}-2$ goes up significantly. It indicates that investors believe that buyback share is a positive signal given by the company related to the future prospects where the company is in good condition so that it is able to buy its shares back on fluctuating economic conditions.

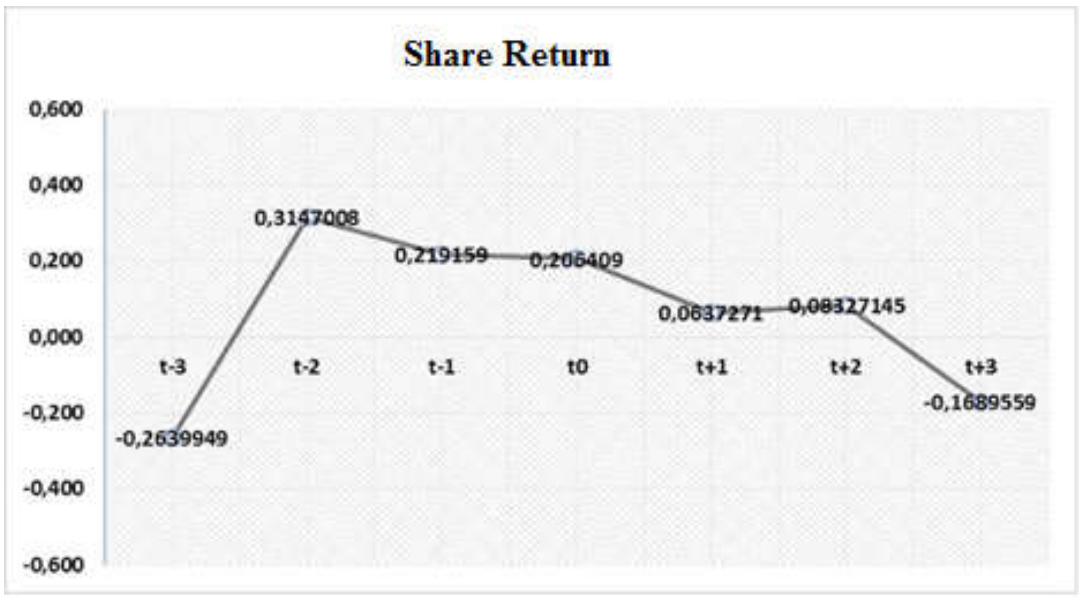

Figure 2 - The Movement of Average Sample Return Share during Windows Period of Buyback Share Announcement in Year of 2011-2015 (Source: BAPEPAM-LK and BEI that have been reprocessed for this study, 2017)

The figure above shows an upward trend on the period before the implementation of buyback share, but after the implementation of buyback share, the trend of the graphic shown tends to decrease until the day $t+3$ shows the value of $-0,16895$. The decrease from graph can be caused by the decrease of investor's interest in the company conducting buyback share. However, when it is viewed from the graph of share return movement in which the initial returns on $t-3$ is negative then on $t+3$, it is back to have negative value. Thus, it is seen the tendency of investors in buying stocks at certain price limits so that when the stock prices have increased, then investors get the excess value of the difference between the stock prices of the purchased company.

Share return on the event of buyback share implementation in which stock returns on average after the implementation of buyback share is smaller when compared to before the buyback share. It explains that the information brought in is in relation to buyback share announcement has not been able to provide a profit more around the date of the implementation of buyback share, especially on period after the implementation of buyback share, (Howe and Lin, 1992). However, investors can still earn returns on certain days before and after buyback share announcement of companies such as on $\mathrm{t}-2, \mathrm{t}-1, \mathrm{t} \mathrm{0}, \mathrm{t}+1$, and $\mathrm{t}+2$.

The effect of buyback share action is the existence of the company's stock price, because that is the advantage of buyback share action. On the rise of stock prices are causing the occurrence of stock returns, if the interest of the investor is to seek profit from capital gain, then on $\mathrm{t}-2$ before implementation is the right time to sell the stock. It is due to share return reaches the highest value in the observation period. But, if investors who intend to profit from dividends, then it will be long enough to get the dividend. It refers to the 
condition of the economy that Indonesia is facing, when cash of companies is quite large, the consideration of the company is to dividend distribution or allocated for expansion of the company, if the company's management considers that the company has not been able to do expansion or other corporate action, then the company will dividend on to investors. However, if the company is willing to do the expansion or willing to stabilize the condition of the company like when price of shares goes down due to worsening economic conditions, then the choice of the company is to conduct buyback share if the company assesses that the stock price is overvalued, then the management parties will do a stock split, or if the company will issue new shares, then the company will offer a right issue to potential investors.

Trading Reaction Volume Activity above Buyback Share. Trading volume activity is the sale of each transaction that occurs in the stock exchange at the time and certain shares, and is one of factors that also gives effect towards stock price movements. This share price movement is related to the motivation of investors in buying and selling stocks. Trading volume activity can be used to test the hypothesis of efficient market on the weak form (weak-form efficiency because of the market is not efficient yet or efficient in the weak form, price changes not yet immediately reflects the existing information so that the researcher only can observe the reaction of the capital market through the movement of trading volume inflammation on the researched capital market.

Table 7 - Table of Company's Average Trading Volume Activity

\begin{tabular}{|c|c|}
\hline Period & Average \\
\hline $\mathrm{t}-3$ & 0,00128 \\
\hline $\mathrm{t}-2$ & 0,00159 \\
\hline $\mathrm{t}-1$ & 0,00174 \\
\hline $\mathrm{t} 0$ & 0,00324 \\
\hline $\mathrm{t}+1$ & 0,00258 \\
\hline $\mathrm{t}+2$ & 0,00186 \\
\hline $\mathrm{t}+3$ & 0,00157 \\
\hline
\end{tabular}

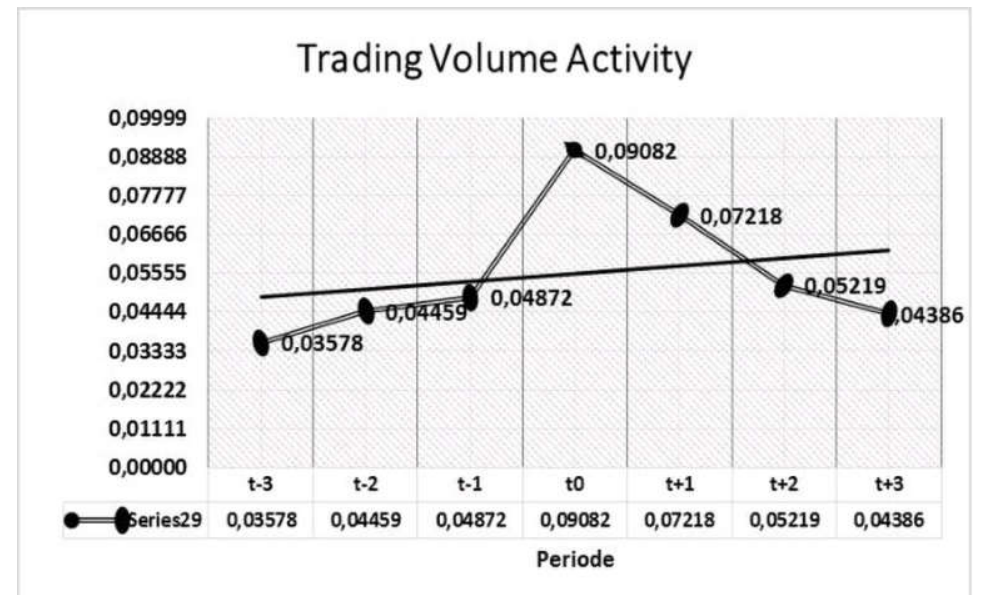

Figure 3 - The Movement of Average TVA Samples during Windows Period of Buyback Share Announcement in Year of 2011-2015 (Source: BAPEPAM-LK and BEI that have been reprocessed for this study, 2017)

Stock trade reaches its peak on the day $\mathrm{t}-0$ or when the company makes a buyback share of 0,09082 . In addition, on average, trading volume activity for three days before implementation of 0,004887 , and average trading volume activity for three days after the implementation of 0,006008 . Therefore, there is an increase in trading volume activity before and after the implementation of buyback share of 0,001121 or an increase amounts to $81,34 \%$. The increase of trading volume activity on $t_{0}$ occurs as new markets react to corporate action at the same time, that is, when a company undertakes buyback share. It occurs as the result of uneven information dissemination on the market so investors cannot 
anticipate buyback share action by buying the shares of the company; however the increase in $t_{0}$ gradually decreases in the period after the implementation of buyback share. It indicates that the majority of investors expects a high abnormal return after the implementation of buyback share, but because the majority of investors buy shares company at the time of buyback share implementation and the minority of investors buys shares in the period after the implementation so that abnormal return is not big as well. It is possible because of the retardation in the information that resulted in slow stock price increases resulting in stock returns and abnormalities of stock returns that should be able to increase and to have positive value after the implementation of buyback share, tends to decrease or even have negative value.

Trading volume activity decreases in the period after the company realizes the buyback shares can also be stated that investors are only looking for abnormal returns after the implementation of the buyback shares, so after getting the abnormal return, investors resell their shares. This is what keeps the value of the company's stock price is not likely to increase on a regular basis maximum. Based on the above conditions, it invites an assumption that investors are less responsive towards the announcement of buyback share previously by not doing stock trading activity so the stock price of the company has not increased significantly and trading volume has not been able to increase in together with the interest of investors to buy the stock.

The difference of daily average trading activity volume before and after this stock buyback can be caused by, due to a positive conveyed through buyback share announcement implicating on the growing volume of stock trading bought by investors in the capital market. Positive signals may be in the form of a stock market price assessed by investors as undervalue because the condition of capital markets which is on the decrease and with the company which realizes buyback share, the investors assume that there are prospects both in the future so that investors buy shares of the company to get an abnormal stock return. The positive signal may also be due to free cash flow in the company. Besides, for testing the average trading volume activity for three days before and after in windows period, it is not found that there is a difference of trading volume activity before and after buyback share. It opens possibility that there has been no major change in trading volume activity during windows period from buyback share.

The investors in the implementation of buyback share are less responsive after the action of the company proven in the period after the implementation of buyback share of trading volume share gradually decreases to $t+3$. It leads to the assumption that decrease in purchases of company shares resulting from returns on stock cannot be maximally returned. It is because one of the motivations of the investor is to profit from the difference in purchase price and the selling price of the company's shares.

Reaction of Bid-Ask Spread on Buyback Share.

Bid ask spread is defined as the difference between the price asked to buy (bid price with the price offered for sell (ask price in stock trading at stock exchange). In the study of bid-ask spread related to measuring tools to measure information is not symmetrical (asymmetric information between dealers and investors.

Table 8 - Table of Company's Average Bid Ask Spread

\begin{tabular}{|c|c|}
\hline Period & Average \\
\hline $\mathrm{t}-3$ & 0,01839 \\
\hline $\mathrm{t}-2$ & 0,02087 \\
\hline $\mathrm{t}-1$ & 0,02386 \\
\hline $\mathrm{t} 0$ & 0,02867 \\
\hline $\mathrm{t}+1$ & 0,02838 \\
\hline $\mathrm{t}+2$ & 0,03002 \\
\hline $\mathrm{t}+3$ & 0,02566 \\
\hline
\end{tabular}




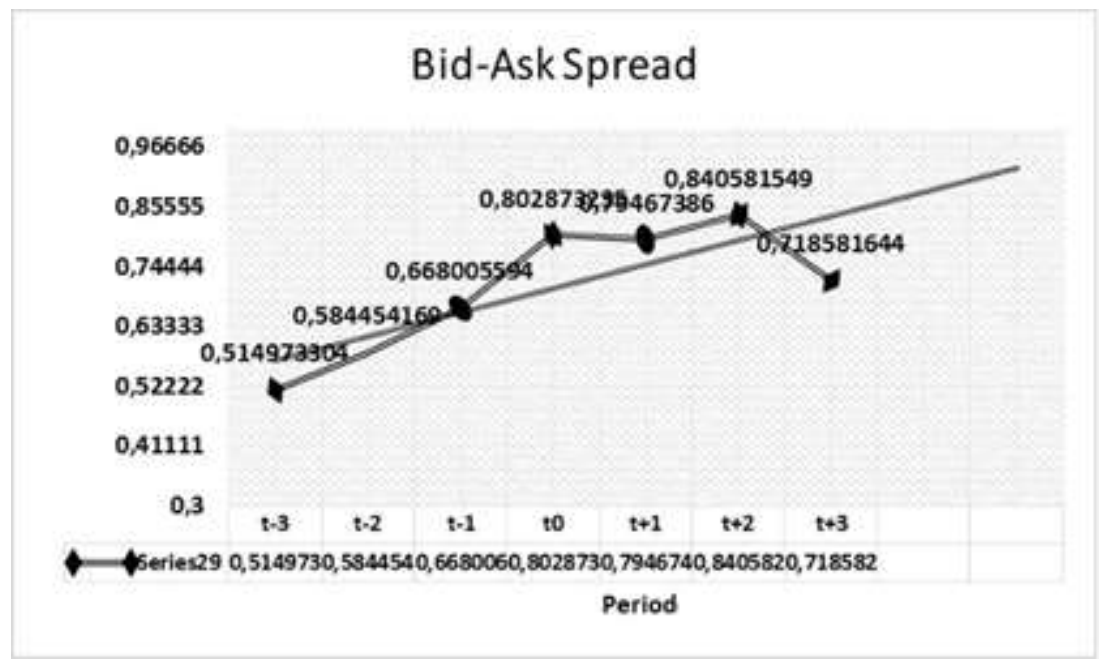

Figure 5 - The Movement of Average BAS Sample during Windows Period of Buyback Share Announcement in Year of 2011-2015 (Source: BAPEPAM-LK and BEI that have been reprocessed for this study, 2017)

The average bid ask spread for three days prior to implementation of buyback share of 0,021041 , and average bid ask spread for three days after the implementation of buyback share of 0,028022 . Thus, there is a bid ask spread increase after the announcement of buyback shares of 0,006981 or $7.5 \%$. The increase of bid ask spread signs that the stock of the company purchased is greater than from shares of companies sold by investors. It is one of the things desired by the company after the implementation of buyback share done.

Information given by the company regarding to implementation of buyback share that will be performed is a signal to investors that the company is able to survive in that worse economy, after the company provides information to the market through public announcement, the flow of such information will be received by all market players, both investors and dealers of the market reacting positively will buy the shares of the company that will buy shares back, so that before the implementation of buyback share, the price of stocks will go up even though it is not significant.

\section{CONCLUSION}

Based on the results of research, then this study obtains the conclusion that in testing the first hypothesis, it shows that on average abnormal return of shares prior to the implementation of buyback share is greater than after the implementation of buyback share. Abnormal return of shares after the implementation of buyback shares of 0,0018 . The negative value of the abnormal return of the stock indicates that the expectation return of the company's shares are much larger than actual return that occur after the implementation of buyback share, but on the period before and after the implementation of buyback share, still there is an abnormal return on certain days before and after buyback share such as on $\mathrm{h}-2$, $\mathrm{h}-1, \mathrm{~h} 0$, and $\mathrm{h}+1$. The difference of abnormal return is found on certain days around the execution date of buyback share. Thus, the buyback share is still carrying information content or specific signals that may affect the decision of the investor in making transactions over the normal decision. Investors can still get abnormal return from buyback shares that the company does but only on certain days before and after the implementation of buyback share.

The testing on the second hypothesis is not much different, that is on average share returns before buyback share is greater than after the implementation of buyback share, share return of the company after the implementation of buyback share is $-0,0002$. The decrease in stock returns even has negative value is caused by price of company's shares which keeps decreasing after the implementation of buyback share. It causes the stock returns drop down to negative value, but in the period before and after the implementation of 
buyback share, there are still returns on certain days before and after buybacks such as on $\mathrm{h}-2, \mathrm{~h}-1, \mathrm{~h} 0, \mathrm{~h}+1$, and $\mathrm{h}+2$. The difference on share returns of companies conducting buybacks show that the profit rate resulted by the implementation of buyback share is less in a positive response by investors, although in the observation period there is still average share return on before and after the implementation of buyback share on certain days.

The results of the third hypothesis test show that on average, average trading volume activity after the implementation of buyback share is greater than before the implementation. Therefore, the implementation of buyback share can still increase the volume of stock trading on period after its implementation. Trading volume activity is increasing but not proportional to the increase of abnormal share return and share returns occur because investors buy shares at a certain price limit, so that the increase in share trading volume does not increase maximally as well.

The fourth hypothesis after the test results shows that the bid-ask spread after the implementation of buyback share is greater than before the buyback share. Hence, the implementation of the buyback share brings the information content to investors, so that the implementation of buyback share can reduce information imbalance (asymmetric information among dealers, then it makes bid-ask spread increase.

\section{REFERENCES}

1. Brown, C. (2007). The announcement effects of off-market share repurchases in Australia. Australian Journal of Management, 32(2), 369-385.

2. Chemmanur, T. J., \& Li, Y. (2014). The role of institutional investors in open-market share repurchase programs. Available at SSRN.

3. Fama, E. F. (1998). Market efficiency, long-term returns, and behavioral finance. Journal of financial economics, 49(3), 283-306.

4. Feeney, L., Haines Jr, G. H., \& Riding, A. L. (1999). Private investors' investment criteria: insights from qualitative data. Venture Capital: An international journal of entrepreneurial finance, 1(2), 121-145.

5. Ghozali, I. (2012). Application of Multivariate Analysis with IBM Program SPSS 20. Diponegoro University Publishing Agency Semarang.

6. Hackethal, A., \& Zdantchouk, A. (2006). Signaling power of open market share repurchases in Germany. Financial Markets and Portfolio Management, 20(2), 123-151.

7. Howe, J. S., \& Lin, J. C. (1992). Dividend Policy and The Bid-Ask Spread: an Empirical Analysis. Journal of Financial Research, 15(1), 1-10.

8. Huang, H., \& Zhou, Z. G. (2007). Stock repurchase and the role of signaling: A comparative analysis between US and China. Journal of Modern Accounting and Auditing, 3(2), 56-62.

9. Jegadeesh, N., \& Titman, S. (1993). Returns to buying winners and selling losers: Implications for stock market efficiency. The Journal of finance, 48(1), 65-91

10. Jogiyanto, H. (2013). Portfolio Theory and Investment Analysis. (8th ed.). BPFE UGM: Yogyakarta.

11. Kollmann, T. (2006). What is e-entrepreneurship?-fundamentals of company founding in the net economy. International Journal of Technology Management, 33(4), 322-340.

12. Nazir, M. (2005). Research Method 16. Jakarta: Ghalia Indonesia.

13. Veronica Siregar, S., \& Bachtiar, Y. (2010). Corporate social reporting: empirical evidence from Indonesia Stock Exchange. International Journal of Islamic and Middle Eastern Finance and Management, 3(3), 241-252. 